the South-East London Health Authority, who estimated that the real cost to the nation of mental illness was $£ 22,066 \mathrm{~m}$ but official expenditure a mere $\$ 4266 \mathrm{~m}$. In light of this constraint they described their work as purchasers. They concluded that we could afford mental health only in areas of low prevalence of mental lliness and if healthy alliances replaced national and local barriers between government departments.

In discussion delegates emphasised the valuable contribution of occupational therapists to making a complete diagnosis. Dr Caldicott stressed that projects would fail if their duration of funding was less than six months at the very least. She said that the College had embarked on a nationwide project to gain information about the mentally ill and was reviewing the role of consultant psychiatrists in multidisciplinary teams.

The conference thanked Ms Judith Reid as the mainspring in organising this provocative, informative and synthesizing event.

Geoffrey Wallis, Consultant Psychiatrist, Harrogate Clinic, 23 Ripon Road, Harrogate HG1 2JL

\title{
Meditation: bringing the mind home
}

\section{Larry Culliford}

\section{Take a deep breath!}

This is a way of bringing the mind into the present moment. This simple exercise is a form of meditation.

The practice of meditation has a lot to do with keeping the mind both tranquil and alert; calm, aware, and focused within the present moment. It is a comfortable experience - that is why meditation is sometimes called. 'Bringing the mind home'.

There are various obstacles; and various techniques are taught to overcome these obstacles.

One of the obstacles involves confusing the practice of a technique with the practice of meditation. The difference is subtle, and in most cases the one leads to the other - but there is a difference.

Confidence and perseverance are necessary. It is often the case that one's practice is proceeding well, even (especially in the early stages) when it does not seem to be.

During the summer I was lucky enough to go on a canoe trip with friends in Canada. We covered about 100 miles in five days. This was on the Spanish River, a beautiful place.

For the final 20 miles or so the water ran swift and smooth. On our map this section was designated a 'Royal Ride' for canoeists, and so it proved. Effortlessly we doubled our previous average speed ... But to get that far we had endured four days of paddling: running aground. capsizing, repeatedly emptying the canoe of water, shooting the safer rapids and carrying canoes, tents, equipment and supplies around the more hazardous - including the awesome three-tiered so-called 'Graveyard' rapids, littered with the wreckage of many boats and canoes.

For many, meditation practice is like this difficult at the beginning.

I was new to canoeing, but those I was with were experienced. We had good canoes, good maps, enough food, proper tents and equipment. The weather was fair; and so with guidance I was quickly able to master the techniques and skills of canoeing.

So it was when I began meditation -12 or 13 years ago. But I have seen others give it a try and make only slow or limited progress - trying perhaps to set out upstream, as it were, against the obstacles of gravity and a fast current; perhaps expecting too much too soon.

This is why one is advised to find a good meditation teacher, someone with experience who will help one avoid mistakes and discouragement.

\section{About technique}

Meditation can be practised in any posture: sitting, kneeling, standing, walking or lying down. 
Guidelines on posture help in maintaining alertness, and are usually given by teachers.

Techniques include concentration on the breath, use of mantras, visualisation methods, and others (e.g. loving-kindness/Metta meditation).

(Although often associated with Eastern spiritual practice, both Christian and secular forms or versions of these techniques are used).

The water in the Spanish River down which we canoed had fallen as rain on some of the oldest rocks of the earth's crust, beautiful glaciersculptured pink granite. It flowed in streams through dense forest, mainly spruce and pine, alive now with moose, bears, wolves, eagles, chipmunks, butterflies, before joining beaver and trout on the banks and in the river.

Here we have at least three or four timescales already: the rocks, the trees, the animals, the rain, myself (canoeist) and myself here now, the writer; bringing these several aspects of the past, and of the interconnectedness of things, into the present moment ... as at another time does the reader - through the mind, through the imagination.

Meditation is a form of training for the mind, a form of discipline; it is a process by which the mind is cleared and discovers its own luminosity - and its own connectedness, in the present moment, to all things.

The Spanish River flows on; into a sequence of lakes, eventually through a dam allowing it to provide power and electricity for Toronto, a city more than 300 miles away. Then the water continues on - to Lake Huron, Niagara Falls, Lake Ontario, the St Lawrence River, to the Atlantic Ocean - evaporating eventually to fall again as rain: an endless cycle.

In anticipating this, the future too has a place in the present moment - thus hinting also at the joy to be found in meditation. When boundaries and barriers like those which seem to exist between past, present and future are not so much broken down as seen through, the joy that accompanies wisdom can be first glimpsed, then seen clearly and grasped.

This is the wisdom that comes when everything is witnessed as an integral part of everything else. Bring the mind home, through meditation, and boundaries, obstacles, barriers, differences retreat. Acceptance - rather than denial, powerlessness and frustration - is achieved, thus tranquillity, peace.

Bring the mind home through meditation and each moment in the present is experienced as it truly is: connected right up to eternity.

\section{Now, take another deep breath!}

Larry Culliford, Consultant Psychiatrist, Aldrington House, Hove Community Mental Health Centre, 35 New Church Road, Hove BN3 4AG 